\title{
Degree of phosphorus saturation threshold for minimizing $P$ losses by runoff in cropland soils of Southern Brazil
}

\author{
Leandro Bortolon(1), Paulo Roberto Ernani(2), Elisandra Solange Oliveira Bortolon ${ }^{(1)}$, Clesio Gianello(3), \\ Rodrigo Gabriel Oliveira de Almeida ${ }^{(3)}$, Samuel Welter ${ }^{(3)}$ and Douglas Antônio Rogeri( ${ }^{(4)}$
}

\begin{abstract}
(1)Embrapa Pesca e Aquicultura, Prolongamento da Avenida NS 10, Cruzamento com a Avenida LO 18, Sentido Norte, Loteamento Água Fria Palmas, Caixa Postal 90, CEP 77008-900 Palmas, TO, Brazil. E-mail: leandro.bortolon@embrapa.br, elisandra.bortolon@embrapa.br (2)Universidade do Estado de Santa Catarina, Centro de Ciências Agroveterinárias, Avenida Luiz de Camões, no 2.090, Conta Dinheiro, CEP 88520-000 Lages, SC, Brazil. E-mail: a2pre@cav.udesc.br ${ }^{(3)}$ Universidade Federal do Rio Grande do Sul, Faculdade de Agronomia, Departamento de Solos, Avenida Bento Gonçalves, no 7.712, CEP 90540-000 Porto Alegre, RS, Brazil. E-mail: cgianello@hotmail.com, oalmeida.rodrigo@gmail.com, samucawelterk@yahoo.com.br (4)Faculdades de Itapiranga, Rua Carlos Kummer, no 100, Universitário, CEP 89896-000 Itapiranga, SC, Brazil. E-mail: douglasrogeri@hotmail.com
\end{abstract}

Abstract - The objective of this work was to assess the risk of phosphorus losses by runoff through an index based on the degree of P saturation (DPS), in cropland soils of Southern Brazil. Sixty-five highly representative cropland soils from the region were evaluated. Three labile P forms were measured (Mehlich-1, Mehlich-3, and ammonium oxalate), and four $\mathrm{P}$ sorption indexes were tested (phosphorus single sorption point and $\mathrm{Fe}+\mathrm{Al}$ determined with the three extractors). Water-extractable P (WEP) was used as an index of P susceptibility to losses by surface runoff. The DPS was determined from the ratio between labile $\mathrm{P}$ and each sorption index. DPS values obtained from the ratio between Mehlich-1 $\mathrm{P}$ and the single $\mathrm{P}$ sorption point ranged from 1 to $25 \%$, whereas those from Mehlich-1 $\mathrm{P}$ and $\mathrm{Fe}+\mathrm{Al}$ (ammonium oxalate) ranged from 1 to 55\%. All DPS types were highly correlated with WEP. From a practical stand point, the DPS obtained with both $\mathrm{P}$ and $\mathrm{Fe}+\mathrm{Al}$ extracted with Mehlich-1 can be used to estimate the risk of P losses by runoff in soils of Southern Brazil.

Index terms: eutrophication, runoff, single $\mathrm{P}$ sorption point, water quality.

\section{Limite do grau de saturação de fósforo para minimizar perdas de $P$ por escorrimento superficial em solos agrícolas do Sul do Brasil}

\begin{abstract}
Resumo - O objetivo deste trabalho foi avaliar o risco de perdas de fósforo por escorrimento superficial por meio de um índice baseado no o grau de saturação de P (GSP) no solo, em solos agrícolas do Sul do Brasil. Foram avaliados 65 solos agrícolas representativos da região. Três formas lábeis de $\mathrm{P}$ foram medidas (Mehlich-1, Mehlich-3 e oxalato de amônio), e quatro índices de adsorção de $\mathrm{P}$ foram testados (adsorção de $\mathrm{P}$ em único ponto e $\mathrm{Fe}+\mathrm{Al}$ obtido com os três extratores). O P extraível em água (PEA) foi utilizado como índice de suscetibilidade do $\mathrm{P}$ a perdas por escoamento superficial. O GSP foi obtido a partir do quociente entre a forma lábil de $\mathrm{P}$ e cada índice de adsorção. Os valores do GSP obtidos a partir do quociente entre P Mehlich-1 e a adsorção de $\mathrm{P}$ em único ponto variaram de 1 a $25 \%$, enquanto os entre $\mathrm{P}$ Mehlich-1 e Fe+Al (oxalato de amônio) variaram de 1 a 55\%. Todos os tipos de GSP estiveram altamente correlacionados ao PEA. Do ponto de vista de uso prático, o GSP obtido com $\mathrm{P}$ e Fe+Al extraídos com Mehlich-1 pode ser usado para estimar o risco de perda de P por escorrimento superficial em solos do Sul do Brasil.
\end{abstract}

Termos para indexação: eutrofização, escorrimento superficial, $\mathrm{P}$ em único ponto, qualidade de água.

\section{Introduction}

Phosphorus is an essential crop nutrient that often shows deficient levels in subtropical and tropical soils, requiring high fertilizer levels to promote high crop yields. However, long-term $\mathrm{P}$ application tends to increase its availability above the sufficiency levels for crops, increasing potential $\mathrm{P}$ losses by runoff and also the risk of accelerating eutrophication of freshwater. The role of nonpoint sources of $\mathrm{P}$, from agricultural fields to surface waters, is well documented and recognized in the literature (Nelson \& Shober, 2012). The challenge, considering $\mathrm{P}$ is a nonrenewable source with a finite global mineral reserve, is to improve $\mathrm{P}$ use in agriculture in order to enhance sustainability in the long-term (Cordell et al., 2009). 
Soil conservation practices associated with supporting practices, such as no-tillage, contour planting, and cover crops, can minimize $\mathrm{P}$ losses by runoff. It should be noted, however, that longterm $\mathrm{P}$ applications and no-tillage tend to increase $\mathrm{P}$ concentrations on soil surface (Kleinman et al., 2009; Verbree et al., 2010), increasing potential risks of $P$ losses, even in highly weathered soils (Barbosa et al., 2009; Bertol et al., 2010; Guardini et al., 2012).

In Southern Brazil, specifically in the states of Rio Grande do Sul and Santa Catarina, no-tillage is adopted in approximately 5.0 million ha, and about $70 \%$ of these areas have soil $\mathrm{P}$ availability levels above the sufficiency levels for crop production (Martinazzo, 2006). Approximately 1.5 million of these hectares are cultivated with vegetables, tobacco, and others crops, which require intensive production systems. In this scenario, with the widespread use of no-tillage, most growers have removed terraces and abandoned other basic soil conservation practices, such as contour planting and use of strip crops, in order to save time for operational crop management. This is causing greater soil, water, and P losses, especially since cropland slopes in this region are usually above $15-20 \%$.

Large amounts of $\mathrm{P}$ applied to the soil can saturate its $\mathrm{P}$ sorption capacity, which facilitates runoff losses (Nelson \& Shober, 2012). A long-term study in two important river basins in the state of Rio Grande do Sul showed that soluble $\mathrm{P}$ levels in freshwater are two-fold higher than the eutrophication limit, and that these high $\mathrm{P}$ concentrations are due to nonpoint sources of pollution from agriculture (Diel et al., 2007; Marchezan et al., 2009; Pellegrini et al., 2010). The fact that farmers in Southern Brazil are gradually using broadcast surface $\mathrm{P}$ application, in order to reduce time spent on planting, increases the potential for runoff losses.

Several environmental indexes have been proposed to estimate the risk of $\mathrm{P}$ losses by runoff. The phosphorus index (PI) incorporates, into a single index, factors related to soil management and to the transport of the element in the environment (Sharpley et al., 2012). The PI is the most widely used index throughout the world (Bechmann et al., 2009; Nelson \& Shober, 2012). However, the simple soil test P (STP) (Pote et al., 1996; Nelson \& Shober, 2012), the $\mathrm{P}$ sorption index (PSI) (Sims, 2009), and the degree of P saturation (DPS) (Ige et al., 2005) have also been successfully used for this purpose.

Although the PI is a more accurate and complete index to estimate the risk of $\mathrm{P}$ losses, its important components include the DPS and PSI. Therefore STP has been used to estimate potential P losses or been incorporated as a PI factor because it has shown high correlations with dissolved reactive $\mathrm{P}$ in runoff waters (Wang et al., 2009). The constraints of using only this index, however, are due to the fact that it does not account for soil-specific $\mathrm{P}$ reactions and for other relevant soil properties, such as soil sorption capacity, indicated by the PSI (Beck et al., 2004). Therefore, the DPS has been recognized as an efficient tool for estimating the potential $\mathrm{P}$ released from soil prone to be transported by surface runoff (Beck et al., 2004; Nair et al., 2004). The first approach using the DPS was proposed by Breeuwsma et al. (1995), in which the index was defined as the quotient between $\mathrm{P}$ extracted with ammonium oxalate $\left(\mathrm{P}_{\mathrm{OX}}\right)$ and $\mathrm{P}$ sorption capacity (PSC), showing that it was an efficient tool to predict $P$ losses from acid soils. Leclerc et al. (2001) reported great association between the DPS and water-extractable P (WEP) in several soils (pH 5.4-6.8) of Quebec.

The DPS can be calculated in many ways, based on the STP of a specific region and on the different forms to obtain PSC (Ige et al., 2005; Verbree et al., 2010). Wang et al. (2009), for example, used the STP and PSC estimated both by Mehlich-3 extractable $\mathrm{Al}$ and $\mathrm{Fe}+\mathrm{Al}$ to calculate the DPS in soils of Ontario.

The STP method that has been adopted in Southern Brazil for over 40 years is Mehlich-1 and it can probably be used to calculate the DPS, aiming to improve P use efficiency in tropical and subtropical soils, in order to minimize the impact of agriculture on the $\mathrm{P}$ load to fresh waters. There is a lack, however, of studies regarding the assessment of $\mathrm{P}$ losses by surface runoff in these soils. In the present study, it is expected that the DPS, successfully tested in other regions of the world, might be suitable to estimate the risk of those losses in soils of Southern Brazil (Ige et al., 2005; Casson et al., 2006; Guérin et al., 2007; Wang et al., 2009).

The objective of this work was to assess the risk of phosphorus losses by runoff through an index of soil DPS, in cropland soils of Southern Brazil.

Pesq. agropec. bras., Brasília, v.51, n.9, p.1088-1098, set. 2016 DOI: $10.1590 / \mathrm{S} 0100-204 \mathrm{X} 2016000900008$ 


\section{Materials and Methods}

Sixty-five soil surface samples were collected from the eight most representative cropland soil types in Southern Brazil, i.e., Oxisols, Acrisols, Inceptisols, Alfisols, Entisols, Ultisols, Vertisols, and Mollisols, which are used in a wide range of managements and show a great variety of physical and chemical properties (Table 1). For each soil type, samples were planned to represent a wide range of STP (Mehlich-1) concentrations, with an upper limit of $40 \mathrm{mg} \mathrm{kg}^{-1}$. This STP threshold was used to avoid extremely high STP values and also because it is the reference value that indicates "very high" $\mathrm{P}$ status according to the nutrient guidelines for crops on clayey soils of Southern Brazil (Tedesco et al., 2004). In this case, logarithmic transformation of the data was unnecessary because extremely high $\mathrm{P}$ values were not used, which reduces the chances of obtaining unrealistic results. Considering that clay contents are also used to classify the $\mathrm{P}$ status when using Mehlich extractors, soil samples with a wide variation in this property were selected (Tedesco et al., 2004) (Table 1).

Soil samples were taken from two different depths, according to soil management. Under conventional and reduced tillage, samples were taken in the 0.00 0.20 -m layer; while under no-tillage (minimum of five years of implementation), samples were taken in the $0.00-0.10-\mathrm{m}$ layer, which is the top layer commonly used to evaluate soil fertility in the region (Tedesco et al., 2004). Soil samples were air-dried and ground to pass through a 2-mm sieve prior to the analyses.

Soil $\mathrm{pH}$ in water was determined with an electrode, with 1:1 soil:water ratio. Carbon content was quantified by the dry combustion method (Nelson \& Sommers,

Table 1. Soil properties in 65 samples from cropland Oxisols, Acrisols, Inceptisols, Alfisols, Entisols, Ultisols, Vertisols, and Mollisols in South Brazil.

\begin{tabular}{lccrc}
\hline Soil properties & Minimum & Maximum & Mean & Median \\
\hline $\mathrm{pH}$ & 4.1 & 7.1 & 5.5 & 5.5 \\
Soil clay $\left(\mathrm{g} \mathrm{kg}^{-1}\right)$ & 60 & 790 & 370 & 400 \\
Organic matter $\left(\mathrm{g} \mathrm{kg}^{-1}\right)$ & 5.0 & 181 & 30 & 26 \\
$\mathrm{Al}^{3+}\left(\mathrm{cmol}_{\mathrm{c}} \mathrm{kg}^{-1}\right)$ & 0.0 & 2.2 & 0.3 & 0.2 \\
$\mathrm{CEC}\left(\mathrm{cmol}_{\mathrm{c}} \mathrm{kg}^{-1}\right)^{(1)}$ & 2.9 & 46.1 & 15.0 & 13.9 \\
$\mathrm{Ca}\left(\mathrm{cmol}_{\mathrm{c}} \mathrm{kg}^{-1}\right)$ & 0.21 & 21.9 & 5.9 & 5.5 \\
$\mathrm{Mg}\left(\mathrm{cmol}_{\mathrm{c}} \mathrm{kg}^{-1}\right)$ & 0.13 & 5.6 & 1.9 & 1.7 \\
$\mathrm{P}\left(\mathrm{mg} \mathrm{kg}^{-1}\right)^{(2)}$ & 3.3 & 33.2 & 10.0 & 9.5 \\
\hline
\end{tabular}

${ }^{(1)} \mathrm{CEC}$, cation exchange capacity. ${ }^{(2)} \mathrm{P}$ extracted with Mehlich-1.
1996), and the results were expressed as soil organic matter, using a total organic carbon analyzer (model TOC-VCSH, Shimadzu, Kyoto, Japan), with 1,724 as a conversion factor. Soil clay contents were measured with the densimeter method, with sample dispersion using $0.1 \mathrm{~mol} \mathrm{~L}^{-1} \mathrm{NaOH}$ plus 2 hours of shaking. STP values were determined with four methods: $\mathrm{P}_{\mathrm{M} 1}$, Mehlich-1 (Tedesco et al., 2004), which is the standard method for soil $\mathrm{P}$ extraction in the region; $\mathrm{P}_{\mathrm{M} 3}$, Mehlich-3 (Bortolon \& Gianello, 2008); $\mathrm{P}_{\mathrm{OX}}$, ammonium oxalate at pH 3.0 (Schwertmann, 1964); and WEP (Self-Davis et al., 2009). The amounts of extractable $\mathrm{Ca}, \mathrm{Mg}, \mathrm{Fe}$, and $\mathrm{Al}$ were also determined, using inductively coupled plasma optical emission spectrometry (ICP-OES), with the Optima 7300 DV spectrometer (Perkin Elmer, Wellesley, MA, USA).

The PSI was obtained as an alternative to rapidly estimate PSC in soils, instead of using P sorption isotherms, which are time-consuming, laborious, and relatively expensive and cumbersome (Sims, 2009). For this, a solution of $75 \mathrm{mg} \mathrm{L}^{-1} \mathrm{P}$ as $\mathrm{KH}_{2} \mathrm{PO}_{4}$ was used in a soil:solution ratio of 1:20. Sequentially, samples were placed in an end-over-end shaker and shook for 18 hours, at $25 \pm 2^{\circ} \mathrm{C}$, centrifuged, and then filtered using a $0.45-\mu \mathrm{m}$ filter membrane. $\mathrm{P}$ was determined in the filtered solution using ICP-OES (Sims, 2009). The amount of $\mathrm{P}$ adsorbed in the soil sample was obtained by the difference between the amount of $\mathrm{P}$ added $\left(75 \mathrm{mg} \mathrm{L}^{-1}\right)$ and the concentration of $\mathrm{P}$ in the equilibrium solution. The PSI was then calculated using the expression: PSI $\left(\mathrm{mg} \mathrm{kg}^{-1}\right)=\mathrm{X} / \log \mathrm{C}$, in which $\mathrm{X}$ is the amount $\left(\mathrm{mg} \mathrm{kg}^{-1}\right)$ of the added $\mathrm{P}$ that was adsorbed in the soil sample; and $\mathrm{C}$ is the $\mathrm{P}$ concentration in the filtered solution at equilibrium $\left(\mathrm{mg} \mathrm{L}^{-1}\right)$.

The DPS was calculated from the ratio between labile $\mathrm{P}$ and the soil sorption capacity estimated with the PSI and with $\mathrm{Fe}+\mathrm{Al}\left(\mathrm{mg} \mathrm{kg}^{-1}\right)$ extracted with Mehlich-1, Mehlich-3, and ammonium oxalate; therefore, DPS $=$ extractable $\mathrm{P} / \mathrm{P}$ sorption capacity $\times 100$. The extractable or labile $\mathrm{P}$ is represented by the STP $\left(\mathrm{mg} \mathrm{kg}{ }^{-1}\right)$ quantified here with Mehlich-1, Mehlich-3, and ammonium oxalate. The values for the different parameters used to calculate the DPS are usually expressed on molar basis; however, the $\mathrm{mg} \mathrm{kg}^{-1}$ unit was used in the present study because the STP was obtained with Mehlich-1 and Mehlich-3.

A P sorption coefficient, $\alpha$, is applied to compare the different DPS estimates (Ige et al., 2005). However, $\alpha$

Pesq. agropec. bras., Brasília, v.51, n.9, p.1088-1098, set. 2016 DOI: 10.1590/S0100-204X2016000900008 
values can vary widely (Ige et al., 2005) and, for this reason, an increasing number of researchers are not using it anymore (Vaughan et al., 2007). Ammonium oxalate is the major extractor used to calculate the DPS. However, its implementation in routine soil testing represents another cumbersome step in the methodology. Therefore, in the present study, the Mehlich-1 and Mehlich-3 methods were also tested. The first one was used because it is the standard STP in the Southern Brazil and it is easy to include $\mathrm{Fe}+\mathrm{Al}$ in the determination process, since ICP-OES is adopted in several laboratories. The second one was used because it has been tested in Southern Brazil as an alternative for Mehlich-1 (Bortolon \& Gianello, 2008). The evaluation of different routine soil test $\mathrm{P}$ to calculate the DPS is important for developing a practical DPS measurement methodology, providing an analytical tool suitable for P management (Nair et al., 2004) and that can predict the risk of $\mathrm{P}$ losses by runoff, considering WEP as the potential $P$ form to be lost.

Data were evaluated for their basic statistical attributes (mean, median, and range) using descriptive analyses. The relationship between STP and PSC was determined through Pearson's correlation coefficient at $5 \%$ probability, which was also used to verify the relationship between DPS and STP, and between STP and WEP. The regression analysis was used to evaluate the relationship between WEP and DPS.

\section{Results and Discussion}

Soil test $\mathrm{P}$ values with Mehlich-1 ranged from 3.3 to $33.2 \mathrm{mg} \mathrm{kg}^{-1}$ (Table 1), comprehending very low to excessive classifications, according to local standards. This wide variation in STP values indicates that the selected soils represent a wide range of environments, managements, and fertility levels. In the present study, STP mean values were generally above the P sufficiency level for crop production in Southern Brazil. Martinazzo (2006) reported soil P levels above the sufficiency level in more than $70 \%$ of the 140 soil samples collected from 20 croplands under no-tillage, mostly in the topsoil layer, from $0.00-0.10 \mathrm{~m}$. These high STP values can be explained by increased surface broadcast and in-furrow $\mathrm{P}$ application in the depths limited to $0.05-0.10 \mathrm{~m}$, creating a soil $\mathrm{P}$ gradient in the soil profile (Santos et al., 2008).
A wide variation range was also observed for soil PSC (Table 2). The PSI ranged from 54 to $438 \mathrm{mg} \mathrm{kg}^{-1}$; the lowest values were found in sandy soils and were approximately three times lower than in clayey soils. The sum of $\mathrm{Al}$ and Fe levels, extracted with ammonium oxalate, is also considered a good indicator of PSC in acidic soils (Nair et al., 2004), and its values ranged from 222 to $3,672 \mathrm{mg} \mathrm{kg}^{-1}$, with an average of $1,307 \mathrm{mg} \mathrm{kg}^{-1}$. Higher values of $\mathrm{Fe}+\mathrm{Al}$ calculated with ammonium oxalate were found in soils with higher clay contents, although a high maximum value of 1,797 $\mathrm{mg} \mathrm{kg}{ }^{-1}$ was also obtained for sandy soils. In general, ammonium oxalate extracts greater amounts of $\mathrm{Fe}+\mathrm{Al}$ than Mehlich-1 and Mehlich-3, mainly in soils with higher clay content (Maguire \& Sims, 2002; Nair et al., 2004).

Soil P extracted with Mehlich-3 was, on average, $50 \%$ greater than that extracted with Mehlich-1 (Table 2). The differences between extractors are well documented in the literature, including studies on tropical and subtropical soils (Bortolon et al., 2010; Schlindwein et al., 2011; Bortolon \& Gianello, 2012). Soil $\mathrm{P}$ extracted with ammonium oxalate from all soils was greater than that extracted with Mehlich-1 or Mehlich-3, and the amount extracted increased as soil clay content decreased.

Soil WEP ranged from 0.02 to $1.11 \mathrm{mg} \mathrm{kg}^{-1}$ (Table 2), being, on average, $20 \%$ lower in clayey than in sandy soils, which reflects the higher sorption capacity of the former, making $P$ less susceptible to losses by surface runoff. WEP results, however, were similar to those reported to have negative impact on water quality (Pote et al., 1996). This variable can be an important tool for estimating $\mathrm{P}$ loss potential in regions where data of dissolved reactive $\mathrm{P}$ in runoff are not available, which is the case for most soils in Brazil. Moreover, several studies have shown high correlation between dissolved reactive $\mathrm{P}$ in runoff and WEP (Pote et al., 1996; Sharpley et al., 2001; Davis et al., 2005). According to Wang et al. (2009), these relationships are soil-specific and vary with soil type, soil clay content, slope, and soil management. Because it is impractical to implement a specific environmental soil test $\mathrm{P}$ for each soil type, several efforts have been made to find an agri-environmental soil test that can be applied to the major soils of a given region, considering some soil properties (Ige et al., 2005). Wang et al. (2009) 
also reported higher WEP in sandy soils than in clayey ones, similarly to the findings of the present study.

Sandy soils are widely used in Southern Brazil to grow tobacco (Nicotiana tabacum L.) and horticultural crops, both associated with intensive tillage and manure application. In these cases, conservation management practices must be adopted to reduce the risk of $\mathrm{P}$ losses from croplands to surface waters.

The DPS in all soils ranged from 0.21 to 92.7 (Table 3). The DPS obtained from the ratio between
STP and $\mathrm{Fe}+\mathrm{Al}$, both calculated with ammonium oxalate, is reported to be a suitable indicator of the risk of $\mathrm{P}$ losses by runoff in acidic soils (Nair et al., 2004). Furthermore, soils with DPS values ranging from 25 to $40 \%$ have a high risk of $\mathrm{P}$ loss, either by surface runoff or by leaching (Pautler \& Sims, 2000). On average, the DPS value was $28 \%$ for the ratio between STP and PSC, both obtained with ammonium oxalate. However, this variable ranged from 4.56 to $79.9 \%$, showing great potential for P losses in some soils. In

Table 2. Soil P tests and P sorption capacity, used to calculate the degree of P saturation (DPS), according to clay contents.

\begin{tabular}{|c|c|c|c|c|c|c|c|c|}
\hline \multirow[t]{2}{*}{ Estimate } & \multicolumn{4}{|c|}{ Soil P test ${ }^{(1)}$} & \multicolumn{4}{|c|}{ Soil P sorption capacity ${ }^{(2)}$} \\
\hline & WEP & $\mathrm{P}_{\mathrm{M} 1}$ & $\mathrm{P}_{\mathrm{M} 3}$ & $\mathrm{P}_{\mathrm{OX}}$ & $\mathrm{Fe}+\mathrm{Al}_{\mathrm{M} 1}$ & $\mathrm{Fe}+\mathrm{Al}_{\mathrm{M} 3}$ & $\mathrm{Fe}+\mathrm{Al}_{\mathrm{OX}}$ & $\mathrm{P}_{\mathrm{PSI}} 75$ \\
\hline & \multicolumn{8}{|c|}{ Clay content $>200 \mathrm{~g} \mathrm{~kg}^{-1}$} \\
\hline $\operatorname{Minimum}\left(\mathrm{mg} \mathrm{kg}^{-1}\right)$ & 0.15 & 4.3 & 4.8 & 17.3 & 205 & 849 & 222 & 54 \\
\hline $\operatorname{Maximum}\left(\mathrm{mg} \mathrm{kg}^{-1}\right)$ & 0.97 & 21.5 & 37.4 & 80.6 & 1,976 & 1,631 & 1,797 & 432 \\
\hline Mean $\left(\mathrm{mg} \mathrm{kg}^{-1}\right)$ & 0.43 & 10.5 & 18.8 & 37.7 & 764 & 1,207 & 706 & 162 \\
\hline \multirow[t]{2}{*}{$\operatorname{Median}\left(\mathrm{mg} \mathrm{kg}^{-1}\right)$} & 0.36 & 9.5 & 17.6 & 41.3 & 692 & 1,212 & 702 & 136 \\
\hline & \multicolumn{8}{|c|}{ Clay contents of $201-400 \mathrm{~g} \mathrm{~kg}^{-1}$} \\
\hline $\operatorname{Minimum}\left(\mathrm{mg} \mathrm{kg}^{-1}\right)$ & 0.02 & 3.3 & 4.3 & 10.1 & 694 & 1,118 & 618 & 138 \\
\hline $\operatorname{Maximum}\left(\mathrm{mg} \mathrm{kg}^{-1}\right)$ & 1.11 & 33.2 & 42.3 & 129.8 & 2,281 & 1,528 & 3,222 & 422 \\
\hline Mean $\left(\mathrm{mg} \mathrm{kg}^{-1}\right)$ & 0.44 & 11.0 & 16.5 & 42.7 & 1,051 & 1,309 & 1,400 & 219 \\
\hline \multirow[t]{2}{*}{ Median $\left(\mathrm{mg} \mathrm{kg}^{-1}\right)$} & 0.38 & 9.4 & 13.6 & 37.3 & 905 & 1,288 & 1,170 & 186 \\
\hline & \multicolumn{8}{|c|}{ Clay content of $401-600 \mathrm{~g} \mathrm{~kg}^{-1}$} \\
\hline Minimum (mg kg-1) & 0.08 & 3.6 & 3.5 & 13.4 & 889 & 1,160 & 1,023 & 142 \\
\hline Maximum (mg kg-1) & 0.55 & 14.1 & 15.4 & 59.4 & 1,682 & 1,573 & 3,672 & 371 \\
\hline Mean $\left(\mathrm{mg} \mathrm{kg}^{-1}\right)$ & 0.33 & 8.4 & 9.3 & 31.3 & 1,197 & 1,321 & 1,632 & 266 \\
\hline \multirow[t]{2}{*}{$\operatorname{Median}\left(\mathrm{mg} \mathrm{kg}^{-1}\right)$} & 0.31 & 7.4 & 9.3 & 29.2 & 1,167 & 1,316 & 1,446 & 257 \\
\hline & \multicolumn{8}{|c|}{ Clay content $>600 \mathrm{~g} \mathrm{~kg}^{-1}$} \\
\hline $\operatorname{Minimum}\left(\mathrm{mg} \mathrm{kg}^{-1}\right)$ & 0.21 & 5.2 & 4.3 & 18.4 & 936 & 1057 & 1197 & 228 \\
\hline Maximum (mg kg-1) & 0.68 & 16.8 & 17.3 & 59.6 & 1,779 & 1,615 & 2,500 & 438 \\
\hline $\operatorname{Mean}\left(\mathrm{mg} \mathrm{kg}^{-1}\right)$ & 0.37 & 9.3 & 8.9 & 35.2 & 1,223 & 1,315 & 1,733 & 313 \\
\hline \multirow[t]{2}{*}{ Median $\left(\mathrm{mg} \mathrm{kg}^{-1}\right)$} & 0.38 & 10.4 & 9.7 & 32.4 & 1,212 & 1,317 & 1,795 & 293 \\
\hline & \multicolumn{8}{|c|}{ All soils } \\
\hline $\operatorname{Minimum}\left(\mathrm{mg} \mathrm{kg}^{-1}\right)$ & 0.02 & 3.3 & 3.5 & 10.1 & 205 & 843 & 222 & 54 \\
\hline $\operatorname{Maximum}\left(\mathrm{mg} \mathrm{kg}^{-1}\right)$ & 1.11 & 33.2 & 42.3 & 129.8 & 2,281 & 1,631 & 3,672 & 438 \\
\hline $\operatorname{Mean}\left(\mathrm{mg} \mathrm{kg}^{-1}\right)$ & 0.40 & 10.0 & 14.2 & 38.4 & 1,022 & 1,279 & 1,307 & 230 \\
\hline $\operatorname{Median}\left(\mathrm{mg} \mathrm{kg}^{-1}\right)$ & 0.34 & 9.5 & 12.3 & 33.3 & 964 & 1,287 & 1,292 & 210 \\
\hline
\end{tabular}

${ }^{(1)}$ WEP, water-extractable $\mathrm{P}$; and $\mathrm{P}_{\mathrm{M} 1}, \mathrm{P}_{\mathrm{M} 3}$, and $\mathrm{P}_{\mathrm{OX}}, \mathrm{P}$ extracted with Mehlich-1, Mehlich-3, and ammonium oxalate, respectively. ${ }^{(2)} \mathrm{Fe}+\mathrm{Al}_{\mathrm{M} 1}, \mathrm{Fe}+\mathrm{Al}_{\mathrm{M} 3}$, and $\mathrm{Fe}+\mathrm{Al}_{\mathrm{OX}}, \mathrm{Fe}+\mathrm{Al}$ calculated with Mehlich-1, Mehlich-3, and ammonium oxalate, respectively; and $\mathrm{P}_{\mathrm{PSI}} 75$, single $\mathrm{P}$ sorption point.

Table 3. Range of the degree of P saturation (DPS, \%) and correlation coefficient between DPS and water-extractable P (WEP).

\begin{tabular}{|c|c|c|c|c|c|c|c|c|c|c|c|c|}
\hline \multirow[t]{2}{*}{$\mathrm{DPS}^{(1)}$} & \multicolumn{4}{|c|}{$\mathrm{P}_{\mathrm{M} 1}$} & \multicolumn{4}{|c|}{$\mathrm{P}_{\mathrm{M} 3}$} & \multicolumn{4}{|c|}{$\mathrm{P}_{\mathrm{OX}}$} \\
\hline & $\mathrm{P}_{\mathrm{PSI} 75}$ & $\mathrm{Fe}+\mathrm{Al}_{\mathrm{M} 1}$ & $\mathrm{Fe}+\mathrm{Al}_{\mathrm{M} 3}$ & $\mathrm{Fe}+\mathrm{Al}_{\mathrm{OX}}$ & $\mathrm{P}_{\mathrm{PSI} 175}$ & $\mathrm{Fe}+\mathrm{Al}_{\mathrm{M} 1}$ & $\mathrm{Fe}+\mathrm{Al}_{\mathrm{M} 3}$ & $\mathrm{Fe}+\mathrm{Al}_{\mathrm{OX}}$ & $\mathrm{P}_{\mathrm{PSI} 75}$ & $\mathrm{Fe}+\mathrm{Al}_{\mathrm{M} 1}$ & $\mathrm{Fe}+\mathrm{Al}_{\mathrm{M} 3}$ & $\mathrm{Fe}+\mathrm{Al}_{\mathrm{OX}}$ \\
\hline Minimum $\left(\mathrm{mg} \mathrm{kg}^{-1}\right)$ & 1.03 & 0.21 & 0.26 & 1.01 & 1.14 & 0.29 & 0.26 & 1.53 & 3.21 & 0.84 & 0.80 & 4.56 \\
\hline Maximum $\left(\mathrm{mg} \mathrm{kg}^{-1}\right)$ & 24.7 & 6.7 & 2.9 & 54.4 & 51.8 & 13.6 & 3.7 & 89.8 & 92.7 & 25.2 & 11.2 & 79.9 \\
\hline Mean $\left(\mathrm{mg} \mathrm{kg}^{-1}\right)$ & 5.7 & 1.3 & 0.8 & 10.9 & 8.9 & 2.0 & 1.2 & 15.7 & 21.9 & 4.9 & 3.1 & 28.0 \\
\hline $\operatorname{Median}\left(\mathrm{mg} \mathrm{kg}^{-1}\right)$ & 4.10 & 0.87 & 0.70 & 6.70 & 4.56 & 1.16 & 0.96 & 8.61 & 15.90 & 2.98 & 2.58 & 22.40 \\
\hline $\mathrm{R}^{2}$ & $0.84 * *$ & $0.87 * *$ & $0.95 * *$ & $0.75 * *$ & $0.74 * *$ & $0.54 *$ & $0.69 * *$ & $0.27^{\mathrm{ns}}$ & $0.77 * *$ & $0.70 * *$ & $0.93 * * *$ & $0.61 *$ \\
\hline
\end{tabular}

${ }^{(1)} \mathrm{P}_{\mathrm{M} 1}, \mathrm{P}_{\mathrm{M} 3}$, and $\mathrm{P}_{\mathrm{OX}}, \mathrm{P}$ extracted with Mehlich-1, Mehlich-3, and ammonium oxalate, respectively; $\mathrm{P}_{\mathrm{PSI}} 75$, single $\mathrm{P}$ sorption point; and $\mathrm{Fe}+\mathrm{Al}_{\mathrm{M} 1}, \mathrm{Fe}+\mathrm{Al}_{\mathrm{M} 3}$, and $\mathrm{Fe}+\mathrm{Al}_{\mathrm{OX}}, \mathrm{Fe}+\mathrm{Al}$ calculated with Mehlich-1, Mehlich-3, and ammonium oxalate, respectively. 
addition to this risk, this variable was also associated with WEP $\left(\mathrm{r}=0.61^{*}\right)$, although at a somewhat lower correlation than that achieved with the DPS obtained with other extractors (Figures 1, 2, and 3).
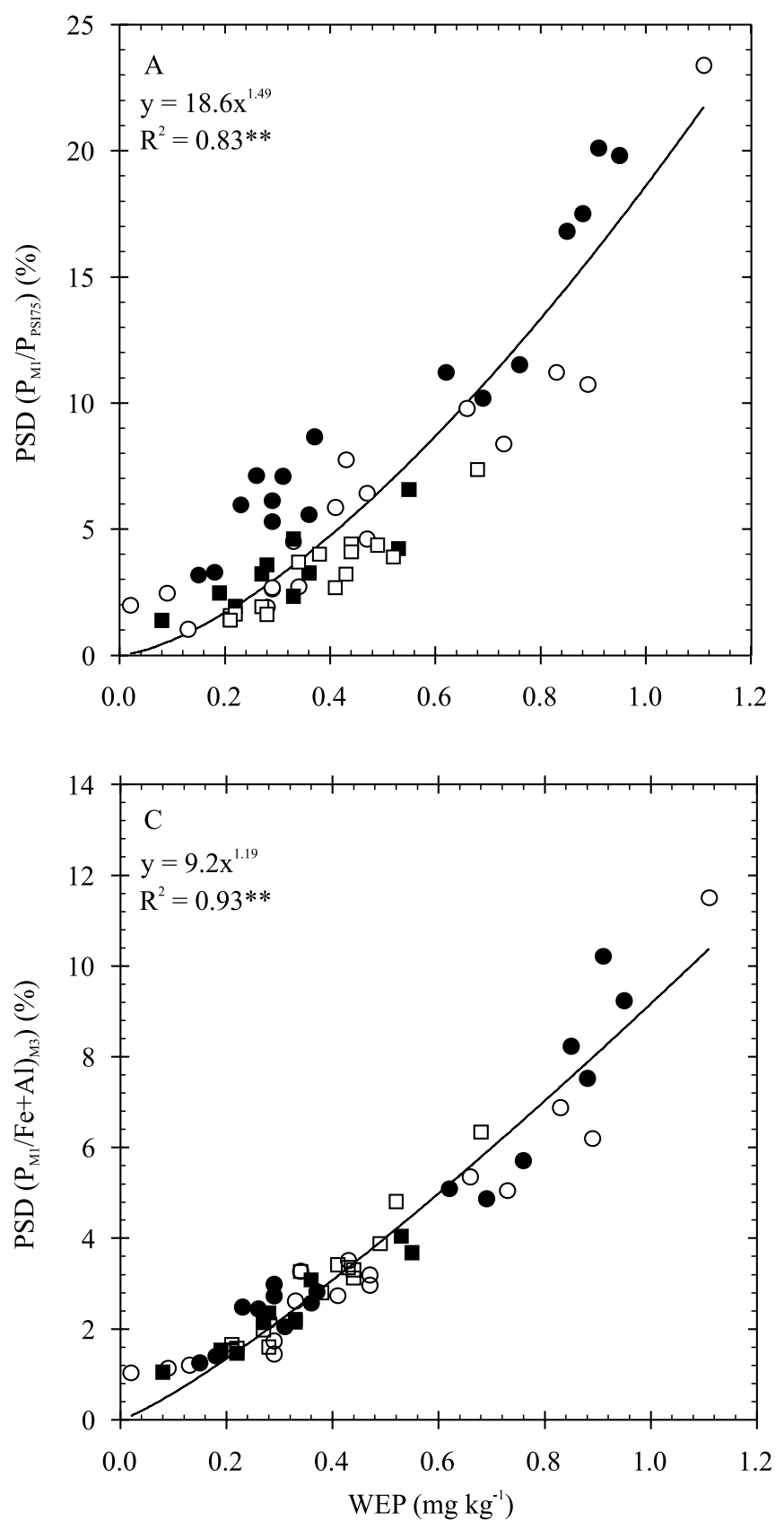

The DPS obtained from the ratio between STP using Melich-1 and $\mathrm{Fe}+\mathrm{Al}$ using Mehlich-3 had the highest correlation with WEP $\left(0.95^{* *}\right)$. This variable was, therefore, adequate to assess the risk of soil $\mathrm{P}$ losses and it is feasible to be implemented in routine soil
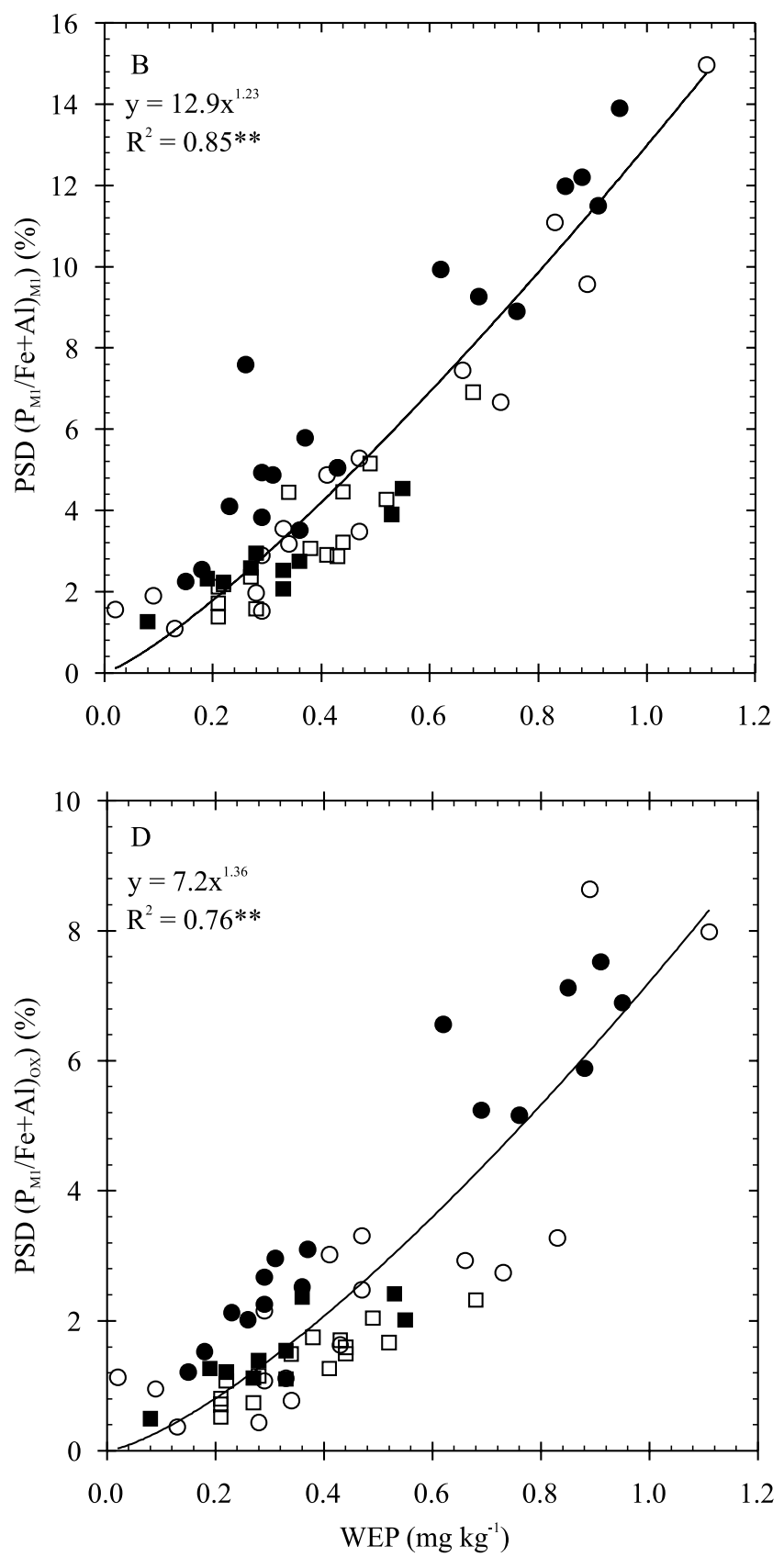

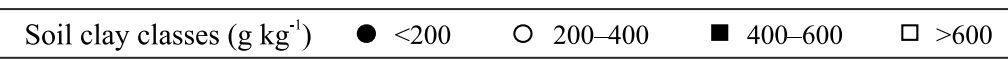

Figure 1. Relationship between water-extractable $\mathrm{P}$ (WEP) and the degree of $\mathrm{P}$ saturation (DPS) determined with different calculation methods, with labile $\mathrm{P}$ obtained with Mehlich-1 $\left(\mathrm{P}_{\mathrm{Ml}}\right) . \mathrm{P}_{\mathrm{PSI}} 75$, single $\mathrm{P}$ sorption point; and $\mathrm{Fe}+\mathrm{Al}_{\mathrm{Ml}}, \mathrm{Fe}+\mathrm{Al}_{\mathrm{M} 3}$, and $\mathrm{Fe}+\mathrm{Al}_{\mathrm{OX}}, \mathrm{Fe}+\mathrm{Al}$ calculated with Mehlich-1, Mehlich-3, and ammonium oxalate, respectively. 
tests (Maguire \& Sims, 2002). Ammonium oxalate is not often used in these tests in Southern Brazil, being only used to determine Fe content in soils (Tedesco et al., 2004). Besides this restriction, extraction with ammonium oxalate must be performed in the dark, and the samples must be shaken for 4 hours, creating constraints for high throughput soil test laboratories.
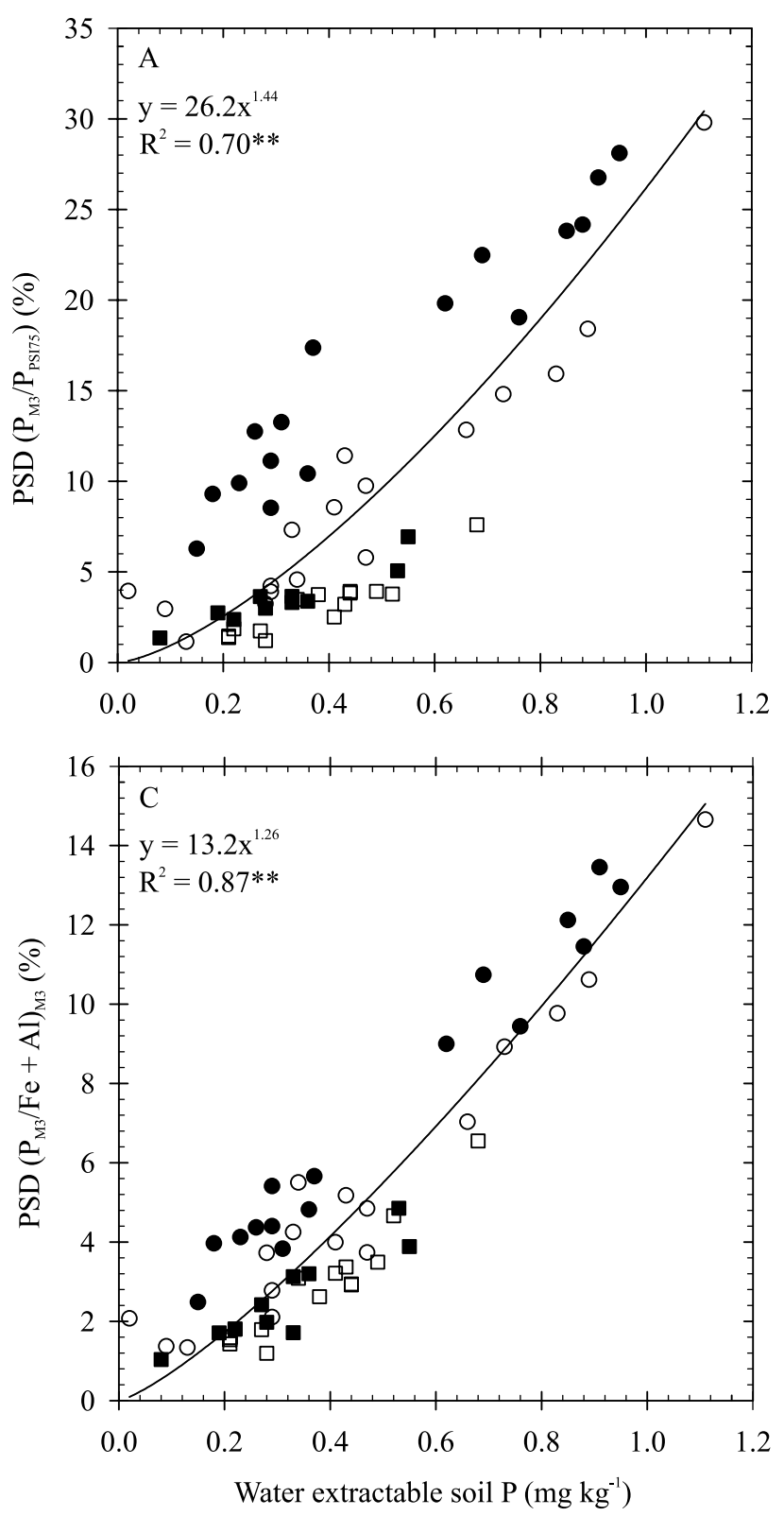

It should be highlighted that Mehlich-1 is the standard method for labile P determination in Southern Brazil (Bortolon \& Gianello, 2010) and that it can be easily used to quantify $\mathrm{Al}$ and $\mathrm{Fe}$, similarly to Mehlich-3. This last extractor, however, is only being used in researches, although there is a tendency to use it for multi-element extraction and determination in soils of Southern Brazil,
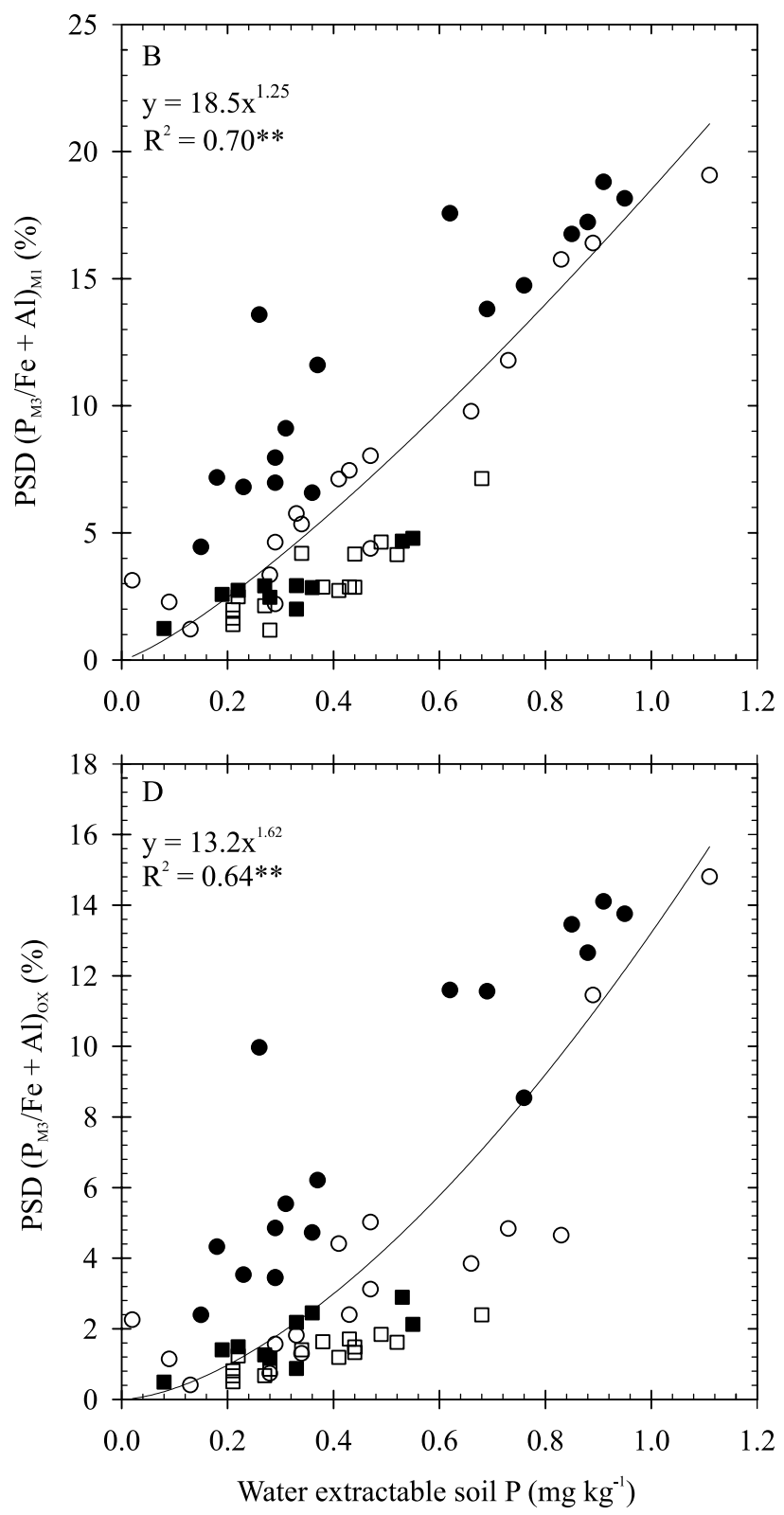

Soil clay classes $\left(\mathrm{g} \mathrm{kg}^{-1}\right)$

$<200$

O $200-400$

- 400-600

$\square>600$

Figure 2. Relationship between water-extractable $\mathrm{P}$ (WEP) and the degree of $\mathrm{P}$ saturation (DPS) determined with different calculation methods, with labile $\mathrm{P}$ obtained with Mehlich-3 $\left(\mathrm{P}_{\mathrm{M} 3}\right) . \mathrm{P}_{\mathrm{PSI}}$ 75, single $\mathrm{P}$ sorption point; and $\mathrm{Fe}+\mathrm{Al}_{\mathrm{M} 1}, \mathrm{Fe}+\mathrm{Al}_{\mathrm{M} 3}$, and $\mathrm{Fe}+\mathrm{Al}_{\mathrm{OX}}, \mathrm{Fe}+\mathrm{Al}$ calculated with Mehlich-1, Mehlich-3, and ammonium oxalate, respectively. 
aiming at the improvement of $\mathrm{P}$ recommendation to crops and at increasing laboratory efficiency (Bortolon et al., 2010; Bortolon \& Gianello, 2012).

The DPS, determined with different extractors, was exponentially adjusted to WEP (Figures 1, 2, and 3). Sandy soils were responsible for the change point in all DPS cases, and ammonium oxalate showed a higher change point than Mehlich-1 and Mehlich-3; however, the correlation coefficients were statistically significant in all cases.

DPS values obtained with different methodologies were highly correlated with each other (Table 4), suggesting that any DPS method could be used to predict the risk of $\mathrm{P}$ loss from cropland to surface waters. The correlations between DPS and P values obtained with Mehlich-3 were generally higher than
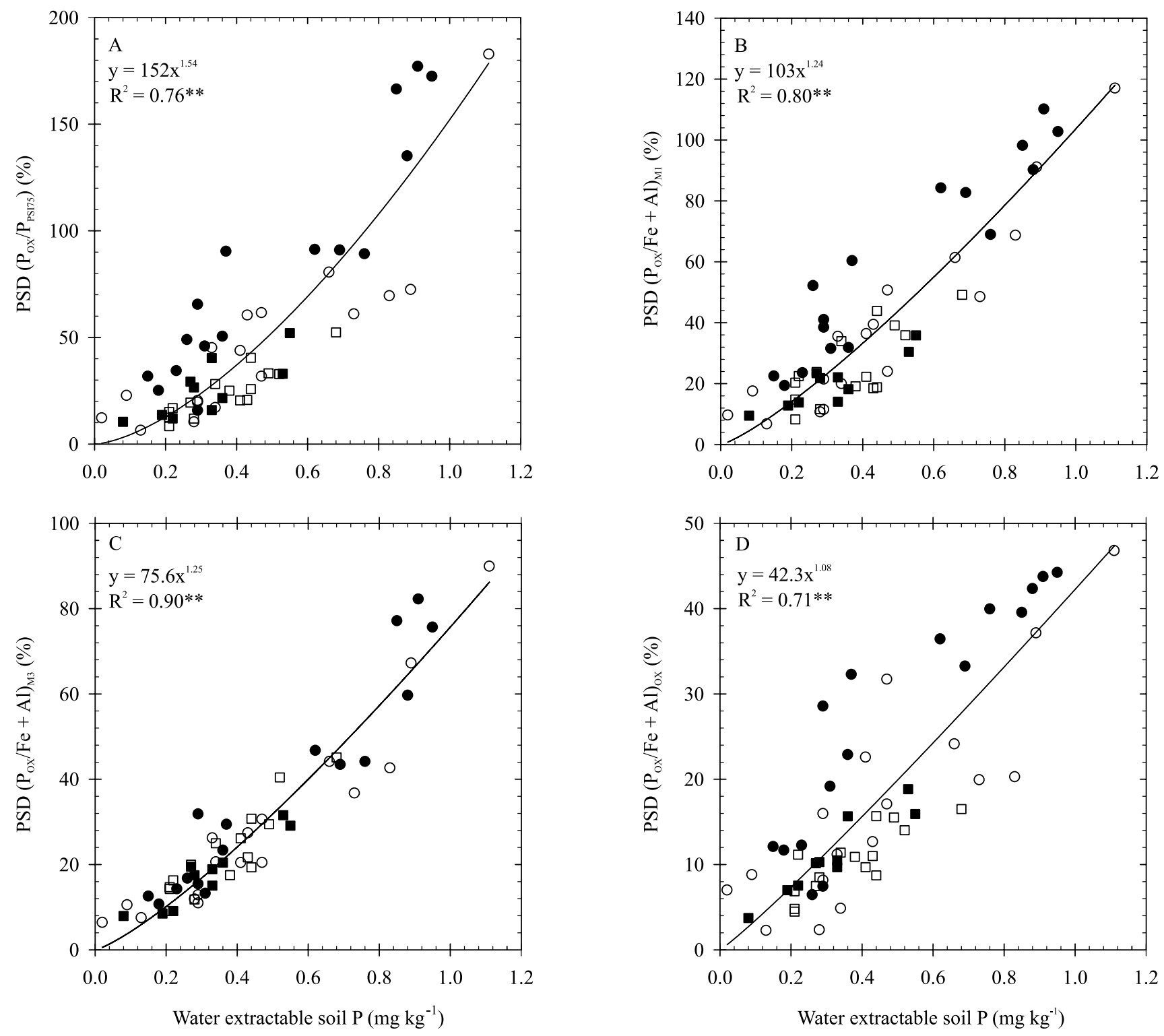

Soil clay classes $\left(\mathrm{g} \mathrm{kg}^{-1}\right)$

$<200$

○ $200-400$

$400-600$

$\square>600$

Figure 3. Relationship between water-extractable $P$ (WEP) and the degree of $P$ saturation (DPS) determined with different calculation methods, with labile $\mathrm{P}$ obtained with ammonium oxalate $\left(\mathrm{P}_{\mathrm{OX}}\right) . \mathrm{P}_{\mathrm{PSI}}{ }_{75}$, single $\mathrm{P}$ sorption point; and $\mathrm{Fe}+\mathrm{Al}_{\mathrm{Ml}}$, $\mathrm{Fe}+\mathrm{Al}_{\mathrm{M} 3}$, and $\mathrm{Fe}+\mathrm{Al}_{\mathrm{OX}}, \mathrm{Fe}+\mathrm{Al}$ calculated with Mehlich-1, Mehlich-3, and ammonium oxalate, respectively. 
Table 4. Correlation coefficients between the different forms for calculating the degree of P saturation (DPS), as well as between the DPS and soil P tests with different extractors ${ }^{(1)}$.

\begin{tabular}{|c|c|c|c|c|c|c|c|c|}
\hline & $\mathrm{P}_{\mathrm{M} 1} / \mathrm{P}_{\mathrm{PSI} 75}$ & $\mathrm{P}_{\mathrm{M} 1} / \mathrm{Fe}+\mathrm{Al}_{\mathrm{M} 1}$ & $\mathrm{P}_{\mathrm{M} 1} / \mathrm{Fe}+\mathrm{Al}_{\mathrm{M} 3}$ & $\mathrm{P}_{\mathrm{M} 1} / \mathrm{Fe}+\mathrm{Al}_{\mathrm{OX}}$ & $\mathrm{P}_{\mathrm{M} 3} / \mathrm{Fe}+\mathrm{Al}_{\mathrm{M} 1}$ & $\mathrm{P}_{\mathrm{M} 3} / \mathrm{Fe}+\mathrm{Al}_{\mathrm{M} 3}$ & $\mathrm{P}_{\mathrm{M} 3} / \mathrm{P}_{\mathrm{PSI}} 75$ & WEP \\
\hline $\mathrm{P}_{\mathrm{M} 1} / \mathrm{P}_{\mathrm{PSI}} 75$ & - & $0.95 * * *$ & $0.85 * *$ & $0.85^{* *}$ & $0.82 * *$ & $0.92 * * *$ & $0.95 * * *$ & - \\
\hline $\mathrm{P}_{\mathrm{M} 1} / \mathrm{Fe}+\mathrm{Al}_{\mathrm{M} 1}$ & - & - & $0.76^{*}$ & $0.92 * * *$ & $0.93 * * *$ & $0.96^{* * *}$ & $0.94 * * *$ & - \\
\hline $\mathrm{P}_{\mathrm{M} 1} / \mathrm{Fe}+\mathrm{Al}_{\mathrm{M} 3}$ & - & - & - & $0.61^{\mathrm{ns}}$ & $0.51^{\mathrm{ns}}$ & $0.75^{*}$ & $0.71^{*}$ & - \\
\hline $\mathrm{P}_{\mathrm{M} 1} / \mathrm{Fe}+\mathrm{Al}_{\mathrm{OX}}$ & - & - & - & - & $0.92 * * *$ & $0.91 * * *$ & $0.89^{* *}$ & - \\
\hline $\mathrm{P}_{\mathrm{M} 3} / \mathrm{Fe}+\mathrm{Al}_{\mathrm{M} 1}$ & - & - & - & - & - & $0.92 * * *$ & $0.92 * *$ & - \\
\hline $\mathrm{P}_{\mathrm{M} 3} / \mathrm{Fe}+\mathrm{Al}_{\mathrm{M} 3}$ & - & - & - & - & - & - & $0.94 * *$ & - \\
\hline $\mathrm{P}_{\mathrm{M} 3} / \mathrm{P}_{\mathrm{PSI} 75}$ & - & - & - & - & - & - & - & - \\
\hline$\overline{\mathrm{P}_{\mathrm{M} 1}}$ & $0.73^{*}$ & $0.75^{*}$ & $0.85 * *$ & $0.56^{\text {ns }}$ & $0.68^{*}$ & $0.79^{*}$ & $0.66^{*}$ & $0.87 * *$ \\
\hline $\mathrm{P}_{\mathrm{M} 3}$ & $0.82 * *$ & $0.83 * *$ & $0.83 * *$ & $0.74 *$ & $0.86^{* *}$ & $0.91 * * *$ & $0.85^{* *}$ & $0.83 * *$ \\
\hline
\end{tabular}

${ }^{(1)} \mathrm{P}_{\mathrm{M} 1}$ and $\mathrm{P}_{\mathrm{M} 3}, \mathrm{P}$ extracted with Mehlich-1 and Mehlich-3, respectively; $\mathrm{P}_{\mathrm{PSI}} 75$, single $\mathrm{P}$ sorption point; $\mathrm{Fe}+\mathrm{Al} 1_{\mathrm{M} 1}, \mathrm{Fe}+\mathrm{Al} 1_{\mathrm{M} 3}$, and $\mathrm{Fe}+\mathrm{Al} l_{\mathrm{OX}}, \mathrm{Fe}+\mathrm{Al}$ calculated with Mehlich-1, Mehlich-3, and ammonium oxalate, respectively; and WEP, water-extractable P.

those obtained with Mehlich-1. WEP, however, had a greater correlation with $\mathrm{P}$ values obtained with Mehlich-1. This further indicates that Mehlich-1 $P$ values can be efficient for calculating the DPS. Similar results were found by Beck et al. (2004), using Mehlich-1 P values as an agri-environmental soil indicator of risk in acidic soils of Virginia. However, the authors stressed that the variability among soils can make its implementation difficult with routine soil tests, because a regression model would be needed for each physiographical region of the state. In the case of Southern Brazil, however, this might be less complicated, since soil clay contents were used to evaluate soil $P$ availability to crops.

WEP values were similar to those of dissolved reactive $\mathrm{P}$ in surface runoff reported in other studies, which ranged from 0.01 to $0.05 \mathrm{mg} \mathrm{L}^{-1} ; 0.1 \mathrm{mg} \mathrm{L}^{-1}$ being considered critical as to the eutrophication risk of lakes and streams (Pote et al., 1996; Sharpley et al., 2012). Sharpley et al. (2001) observed that WEP values equal or above $0.4 \mathrm{mg} \mathrm{L}^{-1}$ represent more than $50 \%$ of the analyzed samples, which is a dissolved reactive $\mathrm{P}$ value above the critical for the eutrophication risk of fresh waters. The median value of WEP in the present study was $0.4 \mathrm{mg} \mathrm{L}^{-1}$, similar to that found by Sharpley et al. (2001), indicating great susceptibility to losses by surface runoff (Table 2).

Assuming the DPS calculated with STP and Al+Fe extracted using Mehlich-1, as well as the WEP critical value of $0.4 \mathrm{mg} \mathrm{L}^{-1}$, a DPS of $4 \%$ can be proposed for soils of Southern Brazil. For soils with DPS values ranging from 4 to $8 \%$, some practices must be adopted to improve nutrient use and fertilization efficiency, such as lower rates, fertilizer placement, time of application, and source, mainly in areas where manure is being used as a nitrogen or even as a phosphorus source. Animal residues in Southern Brazil are often applied in areas with high slopes, in some cases on soils with clay contents ranging from $200-400 \mathrm{~g} \mathrm{~kg}^{-1}$ (Marchezan et al., 2009; Pelegrini et al., 2010). These conditions increase the potential risk of $\mathrm{P}$ losses and, therefore, require better $\mathrm{P}$ management practices to protect soil and water quality over time.

\section{Conclusions}

1. The degree of phosphorus saturation (DPS) obtained with Mehlich-1 is highly correlated with water-extractable $\mathrm{P}$, which makes Mehlich-1 suitable for obtaining an index to estimate the risk of $\mathrm{P}$ losses by runoff in soils of Southern Brazil.

2. The DPS threshold in these soils is $4 \%$, and values above that suggest that $\mathrm{P}$ balance should be negative to reduce the risk of $\mathrm{P}$ loss and the potential eutrophication of surface waters.

\section{Acknowledgements}

To Conselho Nacional de Desenvolvimento Científico e Tecnológico (CNPq) for the post-doc fellowship to the first author.

\section{References}

BARBOSA, F.T.; BERTOL, I.; LUCIANO, R.V.; GONZALEZ, A.P. Phosphorus losses in water and sediments in runoff of the water erosion in oat and vetch crops seed in contour and downhill. Soil Tillage Research, v.106, p.22-28, 2009. DOI: 10.1016/j. still.2009.09.004. 
BECHMANN， M.; STÅLNACKE， P.; KVÆRNØ， S.; EGGESTAD, H.O.; ØYGARDEN, L. Integrated tool for risk assessment in agricultural management of soil erosion and losses of phosphorus and nitrogen. Science of the Total Environment, v.407, p.749-759, 2009. DOI: 10.1016/j.scitotenv.2008.09.016.

BECK, M.A.; ZELAZNY, L.W.; DANIELS, W.L.; MULLINS, G.L. Using the Mehlich-1 extract to estimate soil phosphorus saturation for environmental risk assessment. Soil Science Society of America Journal, v.68, p.1762-1771, 2004. DOI: 10.2136/sssaj2004.1762.

BERTOL, O.J.; RIZZI, N.E.; FAVARETTO, N.; LANA, M. do C. Phosphorus loss by surface runoff in no-till system under mineral and organic fertilization. Scientia Agricola, v.67, p.71-77, 2010. DOI: $10.1590 /$ S0103-90162010000100010.

BORTOLON, L.; GIANELLO, C. Interpretação de resultados analíticos de fósforo pelos extratores Mehlich-1 e Mehlich-3 em solos do Rio Grande do Sul. Revista Brasileira de Ciência do Solo, v.32, p.2751-2756, 2008. Número Especial. DOI: 10.1590/ S0100-06832008000700019.

BORTOLON, L.; GIANELLO, C. Multielement extraction from Southern Brazilian Soils. Communications in Soil Science and Plant Analysis, v.43, p.1615-1624, 2012. DOI: 10.1080/00103624.2012.681733.

BORTOLON, L.; GIANELLO, C. Simultaneous multielement extraction with the Mehlich-1 solution for Southern Brazilian soils determined by ICP-OES and the effects on the nutrients recommendations to crops. Revista Brasileira de Ciência do Solo, v.34, p.125-132, 2010. DOI: 10.1590/S0100-06832010000100013.

BORTOLON, L.; GIANELlO, C.; KOVAR, J.L. Phosphorus availability to corn and soybean evaluated by three soil-test methods for Southern Brazilian soils. Communications in Soil Science and Plant Analysis, v.42, p.39-49, 2010. DOI: 10.1080/00103624.2011.528488.

BREEUWSMA, A.; REIJERINK, J.G.A.; SCHOUMANS, O.F. Impact of manure on accumulation and leaching of phosphate in areas of intensive livestock farming. In: STEELE, K.F. (Ed.). Animal waste and the land-water interface. New York: Lewis, 1995. p.239-249.

CASSON, J.P.; BENNETT, D.R.; NOLAN, S.C.; OLSON, B.M.; ONTKEAN, G.R. Degree of phosphorus saturation thresholds in manure-amended soils of Alberta. Journal of Environmental Quality, v.35, p.2212-2221, 2006. DOI: 10.2134/jeq2006.0085.

CORDELL, D.; DRANGERT, J.-O.; WHITE, S. The story of phosphorus: global food security and food for thought. Global Environmental Change, v.19, p.292-305, 2009. DOI: 10.1016/j. gloenvcha.2008.10.009.

DAVIS, R.L.; ZHANG, H.; SCHRODER, J.L.; WANG, J.J.; PAYTON, M.E.; ZAZULAK, A. Soil characteristics and phosphorus level effect on phosphorus loss in runoff. Journal of Environmental Quality, v.34, p.1640-1650, 2005. DOI: 10.2134/ jeq2004.0480.

DIEL, M.; CASTILHOS, R.M.V.; SOUSA, R.O. de; VALH, L.C.; SILVA, J.B. da. Nutrientes na água para irrigação de arroz na região Sul do Rio Grande do Sul, Brasil. Ciência Rural, v.37, p.102-109, 2007. DOI: 10.1590/S0103-84782007000100017.
GUARDINI, R.; COMIN, D.R.; SANTOS, D.R. dos.; GATIBONI, L.C.; TIECHER, T.; SCHMITT, D.; BENDER, M.A.; BELLI FILHO, P.; OLIVEIRA, P.A.V. de; BRUNETTO, G. Phosphorus accumulation and pollution potential in a hapludult fertilized with pig manure. Revista Brasileira de Ciência do Solo, v.36, p.13331342, 2012. DOI: 10.1590/S0100-06832012000400027.

GUERIN, J.; PARENT, L.E.; ABDELHAFID, R. Agrienvironmental threshold using Mehlich-III soil phosphorus saturation index for vegetables in Histosols. Journal of Environmental Quality, v.36, p.975-982, 2007. DOI: 10.2134/ jeq2006.0424.

IGE, D.V.; AKINREMI, O.O.; FLATEN, D.N. Environmental index for estimating the risk of phosphorus loss in calcareous soils of Manitoba. Journal of Environmental Quality, v.34, p.19441951, 2005. DOI: 10.2134/jeq2004.0468.

KLEINMAN, P.J.A.; SHARPLEY, A.N; SAPORITO, L.S.; BUDA, A.R.; BRYANT, R.B. Application of manure to no-till soils: phosphorus losses by sub-surface and surface pathways. Nutrient Cycling in Agroecosystems, v.84, p.215-227, 2009. DOI: $10.1007 / \mathrm{s} 10705-008-9238-3$.

LECLERC, M.L.; NOLIN, M.C.; CLUIS, D.; SIMARD, R.R. Grouping soils of the Montreal Lowlands (Quebec) according to fertility and $\mathrm{P}$ sorption and desorption characteristics. Canadian Journal of Soil Science, v.81, p.71-83, 2001. DOI: 10.4141/S00021.

MAGUIRE, R.O.; SIMS, J.T. Measuring agronomic and environmental soil phosphorus saturation and predicting phosphorus leaching with Mehlich 3. Soil Science Society of America Journal, v.66, p.2033-2039, 2002. DOI: 10.2136/ sssaj2002.2033.

MARCHEZAN, E.; SARTORI, G.M.S.; REIMCHE, G.B.; AVILA, L.A. de; ZANELLA, R.; MACHADO, S.L. de O.; MACEDO, V.R.M.; COGO, J.P. Qualidade de água dos rios Vacacaí e Vacacaí-Mirim no Estado do Rio Grande do Sul, Brasil. Ciência Rural, v.39, p.2050-2056, 2009. DOI: 10.1590/S010384782009005000158.

MARTINAZZO, R. Diagnóstico da fertilidade de solos em áreas sob plantio direto consolidado. 2006. 126p. Dissertação (Mestrado) - Universidade Federal de Santa Maria, Santa Maria.

NAIR, V.D.; PORTIER, K.M.; GRAETZ, D.A.; WALKER, M.L. An environmental threshold for degree of phosphorus saturation in sandy soils. Journal of Environmental Quality, v.33, p.107113, 2004. DOI: 10.2134 /jeq2004.1070.

NELSON, D.W.; SOMMERS, L.E. Total carbon, organic carbon, and organic matter. In: SPARKS, D.L.; PAGE, A.L.; HELMKE, P.A.; LOEPPERT, R.H.; SOLTANPOUR, P.N.; TABATABAI, M.A.; JOHNSTON, C.T.; SUMNER, M.E. (Ed.). Methods of soil analysis: part 3 - chemical Methods. $2^{\text {nd }}$ ed. Madison: Soil Science Society of America: American Society of Agronomy, 1996. p.961-1010. (Soil Science Society of America Book Series, 5). DOI: 10.2136/sssabookser5.3.c34.

NELSON, N.O.; SHOBER, A.L. Evaluation of phosphorus indices after twenty years of science and development. Journal of Environmental Quality, v.41, p.1703-1710, 2012. DOI: 10.2134/ jeq2012.0342. 
PAUTLER, M.C.; SIMS, J.T. Relationship between soil test phosphorus, soluble phosphorus, and phosphorus saturation in Delaware soils. Soil Science Society of America Journal, v.64, p.765-773, 2000. DOI: 10.2136/sssaj2000.642765x.

PELLEGRINI, J.B.R.; SANTOS, D.R. dos; GONÇALVES, C.S.; COPETTI, A.C.C.; BORTOLUZZI, E.C.; TESSIER, D. Impacts of anthropic pressures on soil phosphorus availability, concentration, and phosphorus forms in sediments in a Southern Brazilian watershed. Journal of Soils and Sediments, v.10, p.451-460, 2010. DOI: 10.1007/s11368-009-0125-6.

POTE, D.H.; DANIEL, T.C.; SHARPLEY, A.N.; MOORE, JR., P.R.; EDWARDS, D.R; NICHOLS, D.J. Relating extractable soil phosphorus to phosphorus losses in runoff. Soil Science Society of America Journal, v.60, p.855-859, 1996. DOI: 10.2136/ sssaj1996.03615995006000030025x.

SANTOS, D.R. dos; GATIBONI, L.C.; KAMINSKI, J. Fatores que afetam a disponibilidade do fósforo e o manejo da adubação fosfatada em solos sob sistema plantio direto. Ciência Rural, v.38, p.576-586, 2008. DOI: 10.1590/S0103-84782008000200049.

SCHLINDWEIN, J.A.; BORTOLON, L.; GIANELLO, C. Soil phosphorus available for crops and grasses extracted with three soiltest methods in Southern Brazilian soils amended with phosphate rock. Communications in Soil Science and Plant Analysis, v.42, p.283-292, 2011. DOI: 10.1080/00103624.2011.538881.

SCHWERTMANN, U. Differenzierung der Eisenoxiden des Bodens durch Extraktion mit Ammoniumoxalat-Lösung. Zeitschrift Für Pflanzenernährung, Düngung, Bodenkunde, v.105, p.194-202, 1964. DOI: 10.1002/jpln.3591050303.

SELF-DAVIS, M.L.; MOORE, P.A.; JOERN, B.C. Water- or dilute salt-extractable phosphorus in soil. In: KOVAR, J.L.; PIERZYNSKI, G.M. (Ed.). Methods of phosphorus analysis for soils, sediments, residuals, and waters. $2^{\text {nd }} \mathrm{ed}$. Virginia: Virginia State University, 2009. p.22-24. (Southern Cooperative Series Bulletin, 408).
SHARPLEY, A.N.; BEEGLE, D.; BOLSTER, C.; GOOD, L.; JOERN, B.; KETTERINGS, Q.; LORY, J.; MIKKELSEN, R.; OSMOND, D.; VADAS, P. Phosphorus indices: why we need to take stock of how we are doing. Journal of Environmental Quality, v.41, p.1711-1719, 2012. DOI: 10.2134/jeq2012.0040.

SHARPLEY, A.N.; MCDOWELL, R.W.; WELD, J.L.; KLEINMAN, P.J.A. Assessing site vulnerability to phosphorus loss in an agricultural watershed. Journal of Environmental Quality, v.30, p.2026-2036, 2001. DOI: 10.2134/jeq2001.2026.

SIMS, J.T. A phosphorus sorption index. In: KOVAR, J.L.; PIERZYNSKI, G.M. (Ed.). Methods of phosphorus analysis for soils, sediments, residuals, and waters. $2^{\text {nd }}$ ed. Virginia: Virginia State University, 2009. p.20-21. (Southern Cooperative Series Bulletin, 408).

TEDESCO, M.J.; GIANELLO, C.; ANGHINONI, I.; BISSANI, C.A.; CAMARGO, F.A.O.; WIETHÖLTER, S. (Ed.). Manual de adubação e de calagem para os Estados do Rio Grande do Sul e de Santa Catarina. Porto Alegre: Sociedade Brasileira de Ciência do Solo, Núcleo Regional Sul, 2004. 400p.

VAUGHAN, R.E.; NEEDELMAN, B.A.; KLEINMAN, P.J.A.; ALLEN, A.L. Spatial variation of soil phosphorus within a drainage ditch network. Journal of Environmental Quality, v.36, p.1096-1104, 2007. DOI: 10.2134/jeq2006.0095.

VERBREE, D.A.; DUIKER, S.W.; KLEINMAN, P.J.A. Runoff losses of sediment and phosphorus from no-till and cultivated soils receiving dairy manure. Journal of Environmental Quality, v.39, p.1762-1770, 2010. DOI: 10.2134/jeq2010.0032.

WANG, Y.T.;ZHANG, T.Q.;HU,Q.C.;TAN,C.S.;O'HALLORAN, I.P.; DRURY, C.F.; REID, D.K.; MA, B.L.; BALL-COELHO, B.; LAUZON, J.D.; REYNOLDS, W.D.; WELACKY, T. Estimating dissolved reactive phosphorus concentration in surface runoff water from major Ontario soils. Journal of Environmental Quality, v.39, p.1771-1781, 2009. DOI: 10.2134/jeq2009.0504.

Received on August 28, 2015 and accepted on May 19, 2016 